\title{
PENERAPAN AKUNTANSI MURABAHAH TERHADAP PEMBIAYAAN KREDIT PEMILIKAN RUMAH PADA BANK SYARIAH MANDIRI CABANG LUWUK
}

\author{
Shindy Marcela Nasir dan Siswadi Sululing \\ Fakultas Ekonomi Universitas Muhammadiyah Luwuk \\ email:siswadi.sululing@yahoo.com
}

\begin{abstract}
The purpose of this study to determine the suitability of the application of accounting murabaha financing at Bank Syariah Mandiri Branch Luwuk to Statement of Financial Accounting Standards No. 102, Accounting for Murabahah. This research includes applied research. Data collection technique used is the technique of documentation and literature. The data used are primary data and secondary data as well as data analysis method used is descriptive qualitative method. Results of the analysis showed that the financing of Housing Loan (KPR) on Bank Syariah Mandiri Branch Luwuk accordance with Statement of Financial Accounting Standards No. 102, Accounting for Murabahah. In the implementation of murabaha financing, Bank Syariah Mandiri Branch Luwuk act as a seller and the customer as a buyer. In addition, there is a difference between the interest of conventional banks and Islamic banks, namely conventional banks determine interest in a contract made with the assumption must sealu profit, while the determination of the ratio of Islamic banks / for the results made a contract based on the likelihood of profit and loss.
\end{abstract}

Keywords: Accounting murabaha, Islamic Bank, Statement of Financial Accounting Standards No. 102.

\begin{abstract}
Abstrak: Tujuan dari penelitian ini untuk mengetahui kesesuaian penerapan akuntansi pembiayaan murabahah pada Bank Syariah Mandiri Cabang Luwuk terhadap Pernyataan Standar Akuntansi Keuangan Nomor 102 tentang Akuntansi Murabahah. Penelitian ini termasuk jenis penelitian terapan. Teknik pengumpulan data yang digunakan adalah teknik dokumentasi dan kepustakaan. Data yang digunakan adalah data primer dan data sekunder serta metode analisis data yang digunakan adalah metode deskriptif kualitatif. Hasil analisis menunjukan bahwa pembiayaan Kredit Kepemilikan Rumah (KPR) pada Bank Syariah Mandiri Cabang Luwuk telah sesuai dengan Pernyataan Standar Akuntansi Keuangan Nomor 102 tentang Akuntansi Murabahah. Di dalam pelaksanaan pembiayaan murabahah, Bank Syariah Mandiri Cabang Luwuk bertindak sebagai penjual dan nasabah sebagai pembeli. Selain itu, terdapat perbedaan antara bunga bank konvensional dan bank syariah yaitu bank konvensional menetukan bunga dibuat pada waktu akad dengan asumsi harus sealu untung, sedangkan bank syariah penentuan besarnya rasio/bagi hasil dibuat waktu akad dengan berpedoman pada kemungkinan untung rugi.
\end{abstract}

Kata kunci: Akuntansi murabahah, Bank Syariah, Pernyataan Standar Akuntansi Keuangan Nomor 102. 


\section{PENDAHULUAN}

Perkembangan industri perbankan syariah di Indonesia saat ini sudah mengalami peningkatan yang cukup pesat dan sudah memiliki tempat yang memberikan cukup pengaruh dalam lingkungan perbankan nasional. Keberadaan perbankan syariah ini dimulai pada saat penerbitan undang-undang No. 7 Tahun 1992 tentang perbankan, dimana undangundang ini menjadi pendorong hadirnya sistem perbankan berbasis syariah.

Dalam perkembangannya, undang-undang tersebut akhirnya diganti ke dalam undangundang No. 10 Tahun 1998 yang menerangkan sistem perbankan syariah dengan lebih jelas dibandingkan undang-undang sebelumnya. Dengan diberlakukannya undang- undang tersebut, perbankan di Indonesia dapat memberlakukan dual banking system atau sistem perbankan ganda, dimana bank konvensional dapat beroperasi berdampingan dengan bank syariah sebagai suatu unit usaha atau bank syariah yang berdiri sendiri. Namun, hal tersebut belum sepenuh mendorong pertumbuhan perbankan syariah yang sebenarnya karena masih terpengaruh kepada sistem perbankan konvensional, sehingga masih sering dipersamakan dengan bank konvensional.

Setelah berjalannya peraturan perbankan yang terakhir, akhirnya diterbitkan undangundang yang lebih spesifik menerangkan tentang perbankan syariah yaitu undang-undang No.21 Tahun 2008.Undang-undang ini menjadikan perbankan syariah sebagai landasan hukum yang jelas dari sisi kelembagaan dan sistem operasionalnya.Dengan kehadiran undang-undang ini memicu peluang yang lebih besar yang diberikan kepada masyarakat untuk mendapatkan pelayanan perbankan sepenuhnya yang sesuai dengan syariat Islam.Salah satunya adalah perbankan syariah menawarkan transaksi yang tidak berlandaskan pada konsep bunga, dapat diharapkanuntuk lebih optimal melayani kalangan masyarakat yang belum dapat tersentuh oleh perbankan konvensional, dan memberikan pembiayaan dalam pengembangan usaha berdasarkan sistem syariat Islam.

Perbankan syariah menjalankan sistem operasionalnya dengan memberlakukan sistem bagi hasil (profit and lost sharing) dan berbagi risiko (risk sharing) dengan nasabahnya yang memberikan penjelasan atas setiap perhitungan keuangan atas transaksi yang dilakukan sehingga akan meminimalisir kegiatan spekulatif dan tidak produktif. Dalam ajaran Islam, sebuah transaksi yang melibatkan dua orang antara pembeli dan penjual tidak boleh ada yang merasa dirugikan. Keduanya harus dapat saling bekerja sama dan melakukan transaksi sesuai dengan kesepakatan yang menandakan bahwa tidak ada salah satu pihak yang merasa dirugikan karena kesepakatan tersebut merupakan sebuah akad (perjanjian) yang telah disetujui bersama.

Dalam hal produk-produk yang ditawarkan oleh bank syariah, produk-produk tersebut sebagian besar memiliki kesamaan dengan yang ditawarkan oleh bank konvensional.Namun, dalam hal penerapannya tentunya berbeda.Hal ini dikarenakan adanya perbedaan prinsip diantara keduanya.

Dalam layanan perbankan syariah yang berhubungan dengan penyaluran dana seperti pemberian pembiayaan kepada nasabah, dapat dilakukan dengan berbagai bentuk akad sesuai dengan kebutuhan dari nasabah sendiri. Salah satu bentuk pembiayaan yang paling sering diberikan kepada nasabah adalah pembiayaan konsumtif untuk memenuhi kebutuhan konsumsi dari nasabah.Pembiayaan konsumtif terbagi dalam beberapa macam produk yang dapat dibiayai, mulai dari barang, mobil, barang-barang mewah, sampai kepada kepemilikan rumah. 
Pemberian pembiayaan kepemilikan rumah di bank syariah umumnya menggunakan akad Murabahah (jual-beli).Akad Murabahah (jual-beli) yaitu akad (perjanjian) jual beli barang, dalam hal ini adalah rumah, dimana si penjual menyatakan harga perolehannya dan marjin(keuntungan) yang diinginkan pada saat penjualan kepada si pembeli atas kesepakatan bersama. Transaksi dengan akad Murabahah (jual-beli) ini dapat dilaksanakan dengan berbagai cara yaitu, dapat berbentuk tunai setelah menerima barang, ditangguhkan dengan cicilan setelah penerimaan barang, ataupun ditangguhkan dengan membayar sekaligus dikemudian hari.

Keunikan dalam perjanjian transaksi yang dimiliki dari akad ini mempengaruhi perlakuan akuntansinya masing-masing.Mulai dari pengakuan, pengukuran, pencatatan, dan pelaporannya.Standar akuntansi 102 tentang akuntansi Murabahah (jual-beli) menjadi acuan dari penerapan perlakuan akuntansi menggunakan akad Murabahah (jual-beli). Didalam standar akuntansi sudah diterangkan mengenai berbagai transaksi yang harus diakui seperti :pada saat penerimaan uang muka nasabah untuk akadMurabahah (jual- beli), pengukuran aset yang diperoleh, pengukuran piutang dan dendanya, pencatatan tiap transaksinya, penyajian laporannya, dan pengungkapan lainnya.

Rumusan masalah dalam penelitian ini adalah: Apakah pembiayaan KPRmenggunakan akad murabahah pada Bank Syariah Mandiri Cabang Luwuk sesuai PSAK No.102 tentang akuntansi murabahah?.

Penelitian ini bertujuan untuk mengetahui kesesuaian penerapan akuntansi pembiayaan murabahah pada Bank Syariah Mandiri Cabang Luwuk terhadap Pernyataan Standar Akuntansi Keuangan No. 102 tentang akuntansi murabahah.

Sedangkan kegunaan penelitian ini adalah: 1) Untuk memberikan masukan bagi Bank Syariah Mandiri Cabang Luwuk untuk pemberian kredit kepemilikan rumah dengan akad pembiayaan murabahah; 2) Menambah menambah wawasan dan ilmu pengetahuan tentang pembiayaan murabahah; dan 3) Sebagai bahan referensibagi peneliti selanjutnya; yang meneliti objek yang sama.

\section{KAJIAN TEORI}

Perbankan Syariah. Pengertian bank menurut Undang-undang No. 21 Tahun 2008 yaitu "Bank adalah badan usaha yang menghimpun dana dari masyarakat dalam bentuk simpanan dan menyalurkan dana tersebut kepada masyarakat dalam bentuk kredit dan/atau bentuk lainnya dalam rangka meningkatkan taraf hidup rakyat".

Sedangkan pengertian bank syariah menurut UU No. 21 Tahun 2008 dalam pasal (1) yaitu: Bank syariah adalah bank yang menjalankan kegiatan usahanya berdasarkan prinsip syariah dan menurut jenisnya terdiri dari bank Umum Syariah dan Bank Pembiayaan Syariah.

Muhammad (2005:1) menyatakan bahwa Bank Syariah adalah lembaga keuangan yang usaha pokoknya memberikan pembiayaan dan jasa-jasa lainnya dalam lalu lintas pembayaran serta peredaran uang yang pengoperasiannya disesuaikan dengan prinsip syariat islam.

Dari pengertian bank dan bank syariah tersebut, dapat disimpulkan bahwa bank syariah adalah lembaga keuangan yang menghimpun dana dari masyarakat dan menyalurkannya kepada masyarakat berdasarkan prinsip-prinsip syariah Islam yaitu berlandaskan Al-Qur'an dan Hadist, sedangkan fungsi Bank Syariah 
Menurut Ismail (2013:39) memiliki 3 (tiga) fungsi 1:fungsi bank syariah yang pertama yaitu menghimpun dana dari masyarakat yang kelebihan dana; fungsi 2: menyalurkan dana kepada masyarakat yang membutuhkan; dan fungsi 3: memberikan jasa pelayanan perbankan kepada nasabah.

Pengertian Pembiayaan. Menurut Undang Undang Perbankan No.10 Tahun 1998, pembiayaan adalah penyediaan uang atau tagihan yang dapat dipersamakan dengan itu, berdasarkan persetujuan atau kesepakatan antara bank dan pihak lain yang dibiayai untuk mengembalikan uang atau tagihan tersebut setelah jangka waktu tertentu dengan imbalan atau bagi hasil. Di dalam perbankan syariah, pembiayaan yang diberikan kepada pihak pengguna dan berdasarkan pada prinsip syariah.Aturan yang digunakan yaitu sesuai dengan hukum Islam.

Menurut IAI (2009:31), pengertian pembiayaan dapat didefinisikan sebagai berikut: "Pembiayaan adalah peminjaman uang atau tagihan yang dapat dipersamakan dengan itu berdasarkan persetujuan atau kesepakatan pinjam-meminjam antara bank dan pihak lain yang mewajibkan pihak peminjam untuk melunasi utangnya setelah jangka waktu tertentu dengan jumlah bunga, imbalan atau pembagian hasil keuntungan".

Pembiayaan atau financing, yaitu pendanaan yang diberikan oleh suatu pihak kepada pihak lain untuk mendukung investasi yang telah direncanakan, baik dilakukan sendiri maupun lembaga, seperti yang dikemukakan oleh Muhammad (2005 :17).

Berdasarkan pengertian diatas, dapat disimpulkan bahwa pembiayaan adalah fasilitas penyediaan dana untuk mendukung investasi yang telah direncanakan berdasarkan kesepakatan antara bank dengan pihak lain yang mewajibkan pihak yang dibiayai untuk mengembalikan uang atau tagihan tersebut setelah jangka waktu tertentu dengan imbalan atau bagi hasil.

Tujuan dan Jenis - jenis Pembiayaan. Secara umum menurut Muhammad (2005 : 18) tujuan pembiayaan dibedakan menjadi 2 (dua) kelompok yaitu:

1. Tujuan pembiayaan untuk tingkat makro. Secara makro tujuan pembiayaan adalah untuk meningkatkan ekonomi masyarakat, tersedianya dana bagi peningkatan usaha, peningkatan produktivitas, membuka lapangan kerja baru, terjadinya distribusi pendapatan.

2. Tujuan pembiayaan untuk tingkat mikro. Secara mikro tujuan pembiayaan adalah untuk memaksimalkan laba, meminimkan risiko, pendayagunaan sumber ekonomi, dan penyaluran kelebihan dana.

Sedangkan jenis-jenis pembiayaan menurut Ismail (2013:113), dilihat dari tujuan penggunaanya, pembiayaan dibagi menjadi 3 (tiga) jenis yaitu: (a) Pembiayaan Investasi, (b) Pembiayaan Modal Kerja, dan (c) Pembiayaan Konsumsi

Perkembangan Standar Akuntansi Khusus Syariah. Seiring dengan berjalannya waktu, ekonomi syariah pun mulai menjadi salah satu fokus di dalam lembaga keuangan, oleh karena itu, keberadaan akuntansi syariah mutlak diperlukan untuk mengimbangi laju perkembangan ekonomi syariah ini. Keberadaan PSAK Syariah yang baik akan mendorong terciptanya sistem akuntansi yang baik pula, sehingga akan tersedia informasi yang dapat dipercaya. Peran keberadaan PSAK Syariah yang matang, berimbas pada perkembangan Lembaga Keuangan Syariah. 
Hingga saat ini Ikatan Akuntan Indonesia (IAI) telah menerbitkan 9 (sembilan) PSAK Syariah yaitu: 1) PSAK 101: Penyajian Laporan Keuangan Syariah; 2) PSAK 102: Akuntansi Murabahah; 3) PSAK 103: Akuntansi Salam; 4) PSAK 104: Akuntansi Istishna'; 5) PSAK 105: Akuntansi Mudharabah; 6) PSAK 106: Akuntansi Musyarakah; 7) PSAK 107: Akuntansi Ijarah; 8) PSAK 108: Akuntansi Transaksi Asuransi Syariah, dan zakat, infak \& sedekah (belum di terbitkan namun sudah disahkan).

Pengertian Murabahah. PSAK No.102 tentang Akuntansi Murabahah paragraf 5:murabahah adalah akad jual beli barang dengan harga jual sebesar biaya perolehan ditambah keuntungan yang disepakati dan penjual harus mengungkapkan biaya perolehan barang tersebut kepada pembeli. (DSAK,2009).

Murabahah adalah akad jual beli atas barang tertentu, di mana penjual menyebutkan harga pembelian barang kepada pembeli kemudian menjual kepada pihak pembeli dengan mensyaratkan keuntungan yang diharapkan sesuai jumlah tertentu.Dalam akad murabahah, penjual menjual barangnya dengan meminta kelebihan atas harga beli dengan harga jual. Perbedaan antara harga beli dan harga jual barang disebut dengan margin keuntungan, seperti yang dikemukakan oleh Ismail (2013:138).

Sedangkan Karim (2004:157) menyatakan bahwa murabahahberarti suatu penjelasan barang seharga barang tersebut ditambah keuntungan yang disepakati, yang merupakan salah satu bentuk natural certainty contracts, sebab dalam murabahah ditentukan jumlah keuntungan yang ingin diperoleh.

Menurut Sri Nurhayati (2011 :168) murabahah adalah transaksi penjualan barang dengan menyatakan harga perolehan dan keuntungan yang disepakati oleh penjual dan pembeli. Pembayaran atas akad dapat dilakukan secara tunai atau tangguh.

Dapat disimpulkan bahwa murabahah merupakan transaksi antara penjual dan pembeli yang biaya perolehan dan keuntungannya dinyatakan dalam transaksi tersebut.

Sedangkan syarat murabahah menurut Antonio (2003:102), syarat Murabahah adalah: (1) Penjual memberi tahu biaya modal kepada nasabah; (2) Kontrak pertama harus sah sesuai dengan rukun yang ditetapkan; (3) Kontrak harus bebas dari riba'; (4) Penjual harus menjelaskan kepada pembeli bila terjadi cacat atas barang sesudah pembelian; (5) Penjual harus menyampaikan semua hal yang berkaitan dengan pembelian, misalnya jika pembelian dilakukan secara hutang.

Menurut Muhammad (2005: 121), sejumlah alasan yang digunakan untuk menjelaskan popularitas murabahah dalam operasi investasi perbankan Islam, yaitu: (1) Murabahah adalah suatu mekanisme jangka pendek dandibandingkan dengan sistem Profit and Loss Sharingcukup memudahkan. (2) Mark up dalam murabahah dapat ditetapkan sedemikian rupa sehingga memastikan bahwa bank dapat memperoleh keuntungan bank-bank berbasis bunga yang menjadi saingan bank-bank Islam. (3) Murabahah menjauhkan ketidakpastian yang ada pada pendapatan dari bisnis-bisnis Profit and Loss Sharing.

Aplikasi Pembiayaan Murabahah Dalam Bank Syariah. Penggunaan Akad Murabahah. Pembiayaan murabahah merupakan jenis pembiayaan yang sering diaplikasikan dalam bank syariah, yang pada umumnya digunakan dalam transaksi jual beli barang investasi dan barang-barang yang diperlukan oleh individu.

1. Jenis penggunaan pembiayaan murabahah lebih sesuai untuk pembiayaan investasi dan konsumsi. Dalam pembiayaan investasi, akad murabahah sangat sesuai karena ada barang yang akan diivestasikan nasabah atau akan ada barang yang menjadi objek 
investasi. Dalam pembiayaan, biasanya barang yang akan dikonsumsi oleh nasabah jelas dan terukur.

2. Pembiayaan murabahah kurang cocok untuk pembiayaan modal kerja yang diberikan langsung dalam bentuk uang.

PSAK 102 Akuntansi Murabahah. Karakteristik PSAK 102. Menurut PSAK nomor 102 paragraf 6: Murabahah dapat dilakukan berdasarkan pesanan atau tanpa pesanan.Dalam murabahah berdasarkan pesanan, penjual melakukan pembelian barang setelah ada pemesanan dari pembeli; paragraf 7: Murabahah berdasarkan pesanan dapat bersifat mengikat atau tidak mengikat pembeli untuk membeli barang yang dipesannya.Dalam murabahah pesanan mengikat pembeli tidak dapat membatalkan pesanannya; paragraf 8: Pembayaran murabahah dapat dilakukan secara tunai atau tangguh; paragraf 9: Akad murabahah memperkenankan penawaran harga yang berbeda untuk cara pembayaran yang berbeda sebelum akad murabahah dilakukan. Namun jika akad tersebut telah disepakati, maka hanya ada satu harga (harga dalam akad) yang digunakan; paragraf 10: Harga yang disepakati dalam murabahah adalah harga jual, sedangkan biaya perolehan harus diberitahukan.Jika penjual mendapatkan diskon sebelum akad murabahah, maka diskon itu merupakan hak pembeli; paragraf 11: Diskon yang terkait dengan pembelian barang, antara lain, meliputi: (1) Diskon dalam bentuk apapun dari pemasok atas pembelian barang; (2) Diskon biaya asuransi dari perusahaan asuransi dalam rangka pembelian barang; (3) Komisi dalam bentuk apapun yang diterima terkait dengan pembelian barang.

Pengakuan dan Pengukuran PSAK 102. Pembayaran Muraba. Pertama. Pembayaran murabahah dapat dilakukan secara tunai atau tangguh. Pembayaran tangguh adalah pembayaran yang dilakukan tidak pada saat barang diserahkan kepada pembeli, tetapi pembayaran dilakukan secara angsuran atau sekaligus pada waktu tertentu. (PSAK 102: Akuntansi Murabahah, paragraph 08). Kedua. Harga yang disepakati dalam murabahah adalah harga jual, sedangkan biaya perolehan harus diberitahukan. Jika penjual mendapatkan diskon sebelum akad murabahah, maka diskon itu merupakan hak pembeli. (PSAK 102: Akuntansi Murabahah, paragraph 10).

Penyajian dan Pengungkapan. Penyajian. Menurut PSAK nomor 102 paragraf 37: piutang murabahah disajikan sebesar nilai bersih yang dapat direalisasikan, yaitu saldo piutang murabahah dikurangi penyisihan kerugian piutang; paragraf 38:margin murabahah tangguhan disajikan sebagai pengurang (contra account) piutang murabahah; paragraf 39: beban murabahah disajikan sebagai pengurang (contra account) hutang murabahah.

Pengungkapan. Menurut PSAK nomor 102 paragraf 40, penjual mengungkapkan hal-hal yang terkait dengan transaksi murabahah, tetapi tidak terbatas pada: (a) Harga perolehan aset murabahah; (b) Janji pemesanan dalam murabahah berdasarkan pesanan sebagai kewajiban atau bukan; dan (c) Pengungkapan yang diperlukan sesuai PSAK 101: Penyajian Laporan Keuangan Syariah.

Menurut PSAK nomor 102 paragraf 41, pembeli mengungkapkan hal-hal yang terkait dengan transaksi murabahah, tetapi tidak terbatas pada: (a) Nilai tunai aset yang diperoleh dari transaksi murabahah; (b) Jangka waktu murabahah tangguh; (c) Pengungkapan yang diperlukan sesuai PSAK 101 
Perlakuan Akuntansi Murabahah. Menurut Ismail (2013:130) Perlakuan akuntansi pembiayaan murabahah dapat dibedakan menjadi 4 (empat) perlakuan.Untuk penjual, untuk pembeli, penyelesaian utang piutang bermasalah untuk penjual,dan penyelesaian utang piutang bermasalah untuk pembeli.

1. Akuntansi Untuk Penjual

A. Pada saat perolehan, aset murabahah diakui sebagai persediaan sebesar biaya perolehan.

$$
\begin{aligned}
& \text { Dr. Aset Murabahah } \quad \text { xxx } \\
& \text { Cr. Kas }
\end{aligned}
$$

B. Jika terjadi penurunan nilai untuk murabahah pesanan mengikat, akan ditanggung penjual.

$$
\begin{array}{ll}
\text { Dr. Beban Penurunan Nilai } & \text { xxx } \\
\text { Cr. Aset Murabahah } & \text { xxx }
\end{array}
$$

Jika terjadi penurunan nilai untuk murabahah pesanan tidak mengikat

$$
\begin{aligned}
& \text { Dr. Kerugian } \\
& \text { Cr. Aset Murabahah }
\end{aligned}
$$

C. Apabila terdapat diskon pada saat pembelian aset murabahah, maka perlakuannya sebagai berikut:

Jika terjadi sebelum akad murabahah, akan menjadi pengurang biaya perolehan aset murabahah.

$$
\begin{aligned}
& \text { Dr. Aset Murabahah (net) } \quad \text { xxx } \\
& \text { Cr. Kas } \\
& \text { xxx }
\end{aligned}
$$

Jika terjadi setelah akad murabahahmenjadi kewajiban kepada pembeli, jika terjadi setelah akad murabahah dan sesuai akad yang disepakati menjadi hak pembeli, menjadi kewajiban kepada pembeli.

$$
\begin{aligned}
& \text { Dr. Kas } \\
& \text { Cr. Utang }
\end{aligned}
$$

Jika terjadi setelah akad murabahah dan sesuai akad yang disepakati menjadi hak penjual, menjadi tambahan keuntungan murabahah.
Dr. Kas
$\mathrm{xxx}$
Cr. Keuntungan Murabahah
$\operatorname{xxx}$

Jika terjadi setelah akad murabahah dan tidak diperjanjikan dalam akad, maka akan menjadi hak penjual dan diakui pendapatan operasional.
Dr. Kas $\mathrm{xxx}$
Cr. Pendapatan operasional lain $\mathrm{xxx}$

D. Kewajiban penjual kepada pembeli atas pengembalian potongan tersebut akan tereliminasi pada saat:

Dilakukan pembayaran kepada pembeli.

$$
\begin{aligned}
& \text { Dr. Utang } \\
& \text { Cr. Kas }
\end{aligned}
$$

akan dipindahkan sebagai dana kebajikan jika pembeli sudah tidak dapat dijangkau oleh penjual:
Dr. Utang
Cr. Kas
Xxx
Dr. Dana Kebajikan-Kas
Cr. Dana Kebajikan-Pot. Pembelian xxx
$\mathrm{XXX}$
$\mathrm{XXX}$

\author{
$\mathrm{xxx}$
}


E. Pada saat akad murabahah, piutang diakui sebesar biaya perolehan ditambah dengan keuntungan yang disepakati. Pada akhir periode laporan keuangan, piutang murabahah dinilai sebesar nilai bersih yang dapat direalisasi (sama dengan akuntansi konvensional). Jurnal untuk penyisihan piutang tak tertagih:

$$
\begin{array}{lll}
\text { Dr. Beban Piutang tak tertagih } & \mathrm{xxx} & \\
\text { Cr. Penyisihan piutang tak tertagih } & & \mathrm{xxx}
\end{array}
$$

F. Pengakuan keuntungan murabahah:

Pada saat terjadinya akad murabahah jika dilakukan secara tunai atau secara tangguh sepanjang masa angsuran murabahah tidak melebihi satu periode laporan keuangan dapat langsung diakui.

$\begin{array}{lll}\text { Dr. Kas } & \mathrm{xxx} & \\ \text { Dr. Piutang Murabahah } & \mathrm{xxx} & \\ \text { Cr. Aset Murabahah } & \mathrm{xxx} & \\ \text { Cr. Keuntungan } & & \mathrm{xxx}\end{array}$

Namun apabila lebih dari satu periode, maka:

1. Keuntungan diakui saat penyerahan aset murabahah dengan syarat apabila risiko penagihannya kecil, jurnal sama dengan butir a.

2. Diakui secara proporsional dengan besaran kas yang berhasil ditagih dari piutang murabahah, jurnal:

Pada saat penjualan kredit dilakukan:

$$
\begin{array}{lcc}
\text { Dr. Piutang Murabahah } & \text { xxx } & \\
\text { Cr. Aset Murabahah } & & \text { xxx } \\
\text { Cr. Keuntungan Tangguhan } & \text { xxx }
\end{array}
$$

Pada saat penerimaan angsuran:

$$
\begin{aligned}
& \text { Dr. Kas } \\
& \text { Cr. Piutang Murabahah } \\
& \text { Dr. Keuntungan tangguhan xxx } \\
& \text { Cr. Keuntungan Murabahah }
\end{aligned}
$$$$
\text { XXX }
$$

XXX

$\operatorname{XXX}$

XXX

G. Potongan pelunasan piutang murabahah diberikan pada saat pelunasan, diakui sebagai pengurang keuntungan murabahah:

Diberikan pada saat pelunasan, jurnal:
Dr. Kas
XXX
Dr. Keuntungan Ditangguhkan xxx
Cr. Piutang Murabahah
Cr. Keuntungan Murabahah
XXX

XXX

Memberikan setelah pelunasan (penjual menerima pelunasan dan membayarkan potongan kepada pembeli). Jurnal:

Pada saat penerimaan piutang dari pembeli:
Dr. Kas
XXX
Dr. Keuntungan Ditangguhkan xxx
Cr. Piutang Murabahah
$\mathrm{XXX}$
Cr. Keuntungan Murabahah
$\operatorname{xxx}$
Dr. Keuntungan Murabahah
Cr. Kas
$\mathrm{XXX}$
$\mathrm{xxx}$

Pada saat pengembalian kepada pembeli:

H. Denda dikenakan jika pembeli lalai dalam melakukan kewajibannya, dan denda yang diterima diakui sebagai bagian dana kebajikan. 


\section{Dr. Dana Kebajikan-Kas \\ $\mathrm{XXX}$ \\ Cr. Dana Kebajikan-Pend.Denda \\ $\mathrm{XXX}$}

I. Pengakuan \& pengukuran penerimaan uang muka adalah sebagai berikut :

Uang muka diakui sebagai uang muka pembelian sebesar jumlah yang diterima;pada saat barang jadi dibeli oleh pembeli maka uang muka diakui sebagai pembayaran piutang (merupakan bagian pokok). Jika barang batal dibeli oleh pembeli maka uang muka dikembalikan kepada pembeli setelah diperhitungkan dengan biaya-biaya yang telah dikeluarkan oleh penjual.

Jurnal yang terkait dengan penerimaan uang muka:

$\begin{array}{lll}\text { Penerimaan uang muka dari pembeli: } & \\ \text { Dr. Kas } & \text { xxx } \\ \text { Cr.Utang Lain-Uang Muka Murabahah } & \text { xxx } \\ \text { Apabila murabahah jadi dilaksanakan: } & \\ \text { Dr.Utang Lain-Uang Muka Mur. } & \text { xxx } & \\ \text { Cr. Piutang Murabahah } & & \text { xxx }\end{array}$

Untuk jumlahmarjin keuntungan berdasarkanatas nilai piutang (harga jual - uang muka).

Pesanan dibatalkan, jika uang muka yang dibayarkan oleh calon pembeli lebih besar daripada biaya yang telah dikeluarkan oleh penjual dalam rangka memenuhi permintaan calon pembeli maka selisihnya dikembalikan pada calon pembeli.
Dr.Utang Lain-Uang Muka Mur.
$\mathrm{xxx}$
Cr. Pendapatan Operasional
$\mathrm{XXX}$
Cr. Kas /Utang
$\mathrm{xxx}$

Pesanan dibatalkan, jika uang muka yang dibayarkan oleh calon pembeli lebih kecil daripada biaya yang telah dikeluarkan oleh penjual dalam rangka memenuhi permintaan calon pembeli, maka penjual dapat meminta pembeli untuk membayarkan kekurangannya, jurnal:
Dr. Kas/Piutang
Dr. Utang Lain-Uang Muka Mur
Cr. PendapatanOperasional
$\operatorname{xxx}$
$\mathrm{xxx}$

Jika pesanan dibatalkan, dan perusahaan menanggung kekurangannya atau uang muka sama dengan beban yang dikeluarkan:

1. Akuntansi untuk pembeli
Dr. Utang Lain-Uang Muka Mur
$\operatorname{xxx}$
Cr. Pendapatan Operasional
XXX
A. UangMuka
Pembeli membayarkan uang muka.
Dr. Uang Muka
$\mathrm{xxx}$
Cr. Kas
xxx

Jika sudah memberikan uang muka, maka ketika penyerahan barang, jurnalnya:
Dr. Aset
$\operatorname{XXX}$
Dr. Beban Murabahah Tangguhan $\quad$ xxx
Cr. Uang Muka
Cr. Utang Murabahah
$\mathrm{XxX}$
$\mathrm{xxx}$

Potongan uang muka akibat pembeli batal membeli barang diakui sebagai kerugian, jurnal"

Dr. Kas

$\mathrm{XXX}$ 
Dr. Kerugian

Cr. Uang Muka $\operatorname{xxx}$

Potongan uang muka akibat pembeli batal membeli barang dan biaya yang dikenakan lebih besar dari besaran uang muka.

Dr. Kerugian

Cr. Uang Muka

Cr. Kas atau Utang

$\mathrm{xxx}$

$\mathrm{XXX}$

$\mathrm{xxx}$

B. Aset yang diperoleh melalui transaksi murabahah tunai (Apabila tidak ada uang muka).

Dr. Aset

$\mathrm{XXX}$

Cr. Kas

$\mathrm{xxx}$

Utang yang timbul dari transaksi murabahah tangguh diakui sebagai hutang murabahah sebesar harga beli yang disepakati (jumlah yang wajib dibayarkan), aset dicatat sebesar biaya perolehan tunai dan selisih antara harga beli yang disepakati dengan biaya perolehan tunai diakui sebagai beban murabahah tangguhan, jurnal:

Dr. Aset

XXX

Dr. Beban Murabahah Tangguhan $\quad$ xxx

Cr. Utang Murabahah xxx

C. Diskon pembelian yang diterima setelah akad murabahah, diperlakukan sebagai pengurang beban murabahah tangguhan.Jurnal Diskon pembelian yg diterima setelah akadMurabahah.

Dr. Kas $\quad$ xxx

Cr. Beban Murabahah Tangguhan $\quad$ xxx

Jurnal potongan pelunasan dan potongan hutang murabahah.

Dr. Utang Murabahah

XXX

Dr. Beban

$\operatorname{XXX}$

Cr.Kas

$\mathrm{XXX}$

Cr. Beban Murabahah Tangguhan

$\mathrm{XXX}$

D. Denda yang dikenakan akibat kelalaian dalam melakukan kewajiban sesuai dengan akad diakui sebagai kerugian.

Dr.Kerugian

XXX

Cr.Kas/Utang

XXX

2. Akuntansi Penyelesaian Utang Piutang Bermasalah-untuk Kreditur atau Penjual

A. Pemberian potongan tagihan murabahah

Potongan ini diakui sebagai pengurang jumlah tercatat marjin/keuntungan murabahah tangguhan

Dr.Keuntungan Murabahah Tangguhan

Cr. Piutang Murabahah

$\mathrm{XXX}$

Atau (jika potongan lebih besar dari marjin)

Dr.Keuntungan Murabahah Tangguhan

$\mathrm{XXX}$

Dr. Kerugian

Cr. Piutang Murabahah

$\mathrm{XXX}$

$\mathrm{XXX}$

$\mathrm{XXX}$

B. Penjadwalan kembali tagihan murabahah

1) Tidak menambah jumlah utang yang tersisa 
2) Perpanjangan masa pembayaran harus berdasarkan kesepakatan kedua belah pihak;

3) Pembebanan biaya dalam proses penjadwalan kembali adalah biaya riil yaitu biaya langsung (direct cost) dari aktivitas kreditor dalam melakukan penjadwalan kembali.

1) Atas pembebanan biaya ini, kreditor mengakuinya sebagai pendapatan.Jurnal:

Dr. Kas/Piutang

XXX

Cr. Pendapatan

$\mathrm{xxx}$

2) Konversi akad murabahah; dilakukan dengan menghentikan akad murabahah dan membuat akad baru dengan skema ijarah muntahiyah bittamlik, mudharabah atau musyarakah.

Akad murabahah dihentikan dengan menjual objek murabahah oleh debitur kepada kreditor dengan harga pasar. Jurnal:

Dr. Aset

$\mathrm{XXX}$

Cr. Kas

$\mathrm{XXX}$

Debitur melunasi sisa utangnya kepada kreditor dari hasil penjualan,jika hasil penjualan lebih besar dari sisa utang. Jurnal :

Dr.Kas $\quad$ xxx

Dr.Keuntungan Murabahah Tangguhan $\quad$ xxx

Cr. Piutang Murabahah xxx

Cr. Keuntungan Murabahah xxx

jika hasil penjualan lebih kecil dari sisa utang maka sisa utang tetap menjadi utang debitur.Jurnal:

$\begin{array}{lc}\text { Dr.Kas } & \mathrm{xxx} \\ \text { Dr Piutang Lain-lain } & \mathrm{xxx} \\ \text { Dr.Keuntungan Murabahah Tangguhan } & \mathrm{xxx} \\ \quad \text { Cr. Piutang Murabahah } & \mathrm{xxx} \\ \text { Cr. Keuntungan Murabahah } & \mathrm{xxx}\end{array}$

jika hasil penjualan lebih kecil daripada nilai tercatat utang dan kreditor membebaskannya maka kurang bayar diakui sebagai kerugian.Jurnal:

Dr.Kas

$\mathrm{XXX}$

Dr.Kerugian

$\mathrm{XXX}$

Dr.Keuntungan Murabahah Tangguhan

$\mathrm{XXX}$

Cr. Piutang Murabahah

$\mathrm{XXX}$

Penyajian. Kerugian yang timbul (jika ada) atas restrukturisasi piutang murabahah disajikan secara terpisah dalam laporan laba rugi.

Pengungkapan. (1) Kreditor mengungkapkan informasi yang berkaitan dengan restrukturisasi piutang murabahah bermasalah meliputi tetapi tidak terbatas padanama debitur, jumlah piutang yang direstrukturisasi, alasan, dan metode restrukturisasi yang digunakan. (2) Kreditor juga mengungkapkan keberadaan hubungan istimewa dengan 
debitur yang direstrukturisasi (jika ada). (3) Akuntansi penyelesaian utang piutang bermasalah-untuk debitur atau pembeli.

A. Pemberian potongan utang murabahah. Jurnal :
Dr. Utang Murabahah
$\operatorname{XXX}$
Cr. Beban Murabahah Tangguhan xxx

Jika nilai tercatat utang lebih besar dari jumlah yang harus dibayar maka selisih tersebut diakui sebagai keuntungan (keuntungan sebesar selisih utang murabahah tercatat dikurangi jumlah yang harus diselesaikan), jurnal:
Dr. Utang Murabahah
XXX
Cr. Beban Murabahah Tangguhan
Cr. Keuntungan
$\mathrm{XXX}$
$\mathrm{xxx}$

B. Penjadwalan kembali tagihan murabahah, dilakukan dengan ketentuan: (1) Tidak menambah jumlah utang yang tersisa; (2) Perpanjangan masa pembayaran harus berdasarkan kesepakatan kedua belah pihak; (3) Pembebanan biaya dalam proses penjadwalan kembali adalah biaya riil yaitu biaya langsung (direct cost) dari aktivitas kreditor dalam melakukan penjadwalan kembali. Atas pembebanan biaya ini debitur mengakuinya sebagai beban.Jurnal:

\section{Dr. Beban \\ Cr. Kas/Utang \\ $\mathrm{XXX}$ \\ $\mathrm{xxx}$}

Penyajian. Keuntungan netto atas restrukturisasi utang murabahah setelah pajak, jika ada, diakui dalam laporan laba rugi dalam periode terjadinya dan disajikan tersendiri sebagai bagian pendapatan non-usaha.

Pengungkapan. Debitur mengungkapkan dalam catatan atas laporan keuangan informasi yang terkait dengan restrukturisasi utang murabahah meliputi tetapi tidak terbatas pada, nama kreditor, jumlah utang yang direstrukturisasi, alasan, dan metode restrukturisasi yang digunakan.

Berikut ini beberapa penelitian terdahulu yang telah dilakukan:

Tabel 1. Penelitian Terdahulu

\begin{tabular}{|c|c|c|c|c|c|}
\hline No & Nama peneliti & Judul Penelitian & $\begin{array}{c}\text { Variabel } \\
\text { Penelitian }\end{array}$ & $\begin{array}{c}\text { Metode } \\
\text { Analisis } \\
\text { Data }\end{array}$ & Hasil Penelitian \\
\hline 1. & $\begin{array}{c}\text { Hayatunufus } \\
\text { Muhammad } \\
\text { Yunus (2013) }\end{array}$ & $\begin{array}{l}\text { Analisis Penerapan } \\
\text { PSAK No } 105 \text { atas } \\
\text { Pembiayaan } \\
\text { Mudharabah pada } \\
\text { Bank Syariah. }\end{array}$ & & $\begin{array}{c}\text { Deskriftip } \\
\text { kualitatif }\end{array}$ & $\begin{array}{l}\text { Pembiayaan } \\
\text { mudharabah di Bank } \\
\text { Muamalat Indonesia, } \\
\text { Tbk diberikan } \\
\text { dalambentuk modal } \\
\text { kerja berupa kas, asset } \\
\text { non kas, dan dalam } \\
\text { menetapkan besarnya } \\
\text { bagi hasil } \\
\text { digunakanmetode } \\
\text { Revenue Sharing dan } \\
\text { pembiayaan } \\
\text { mudhrabah telah } \\
\text { sesuai dengan PSAK } \\
105\end{array}$ \\
\hline
\end{tabular}


Marcella dan Sululing: Penerapan Akuntansi Murabahah Terhadap Pembiayaan Kredit...

\begin{tabular}{|c|c|c|c|c|c|}
\hline No & Nama peneliti & Judul Penelitian & $\begin{array}{c}\text { Variabel } \\
\text { Penelitian }\end{array}$ & $\begin{array}{c}\text { Metode } \\
\text { Analisis } \\
\text { Data }\end{array}$ & Hasil Penelitian \\
\hline 2. & $\begin{array}{c}\text { Dian } \\
\text { Gunawan } \\
(2013)\end{array}$ & $\begin{array}{l}\text { Penerapan PSAK } \\
107 \text { atas Transaksi } \\
\text { Ijarah pada PT. BNI } \\
\text { Syariah Cabang } \\
\text { Makassar. }\end{array}$ & & $\begin{array}{l}\text { Deskriftip } \\
\text { Kualitatif }\end{array}$ & $\begin{array}{l}\text { Hasil penelitian yang } \\
\text { telah dilakukan, } \\
\text { PT.BNI Syariah } \\
\text { Cabang Makassar } \\
\text { telah menerapkan } \\
\text { pengakuan, } \\
\text { pengukuran, serta } \\
\text { penyajian transaksi } \\
\text { ijarah pada laporan } \\
\text { keuangan secara } \\
\text { keseluruhan sesuai } \\
\text { dengan PSAK No } 107 .\end{array}$ \\
\hline 3. & $\begin{array}{l}\text { Banindita } \\
\text { (2013) }\end{array}$ & $\begin{array}{l}\text { Anlisis Penerapan } \\
\text { PSAK } 102 \text { oada } \\
\text { Produk Kepemilikan } \\
\text { Emas dan PSAK } 107 \\
\text { pada Produk Gadai } \\
\text { Emas Padan Bank } \\
\text { BNI Syariah. }\end{array}$ & & $\begin{array}{l}\text { Deskriptif } \\
\text { kualitatif }\end{array}$ & $\begin{array}{l}\text { Secara keseluruhan } \\
\text { bank BNI syariah telah } \\
\text { menjalankan dan } \\
\text { menggunakan } \\
\text { pedomoan akuntansi } \\
\text { PSAk } 102 \text { dan PSAK } \\
107 \text { pada produk } \\
\text { perlakuan } \\
\text { akuntansinya untuk } \\
\text { produk gadai emas dan } \\
\text { kepemilikan emas. }\end{array}$ \\
\hline
\end{tabular}

Sumber:pcinu-mesir.tripod.com/ilmiah/artikel/isartikel/artikel/Artikel96-02/yopi_ syaltut.htm. 
Kerangka Pikir. Merupakan landasan dalam penelitian untuk mengarahkan menjelaskan makna dan maksud dari teori yang dipakai,adalah:

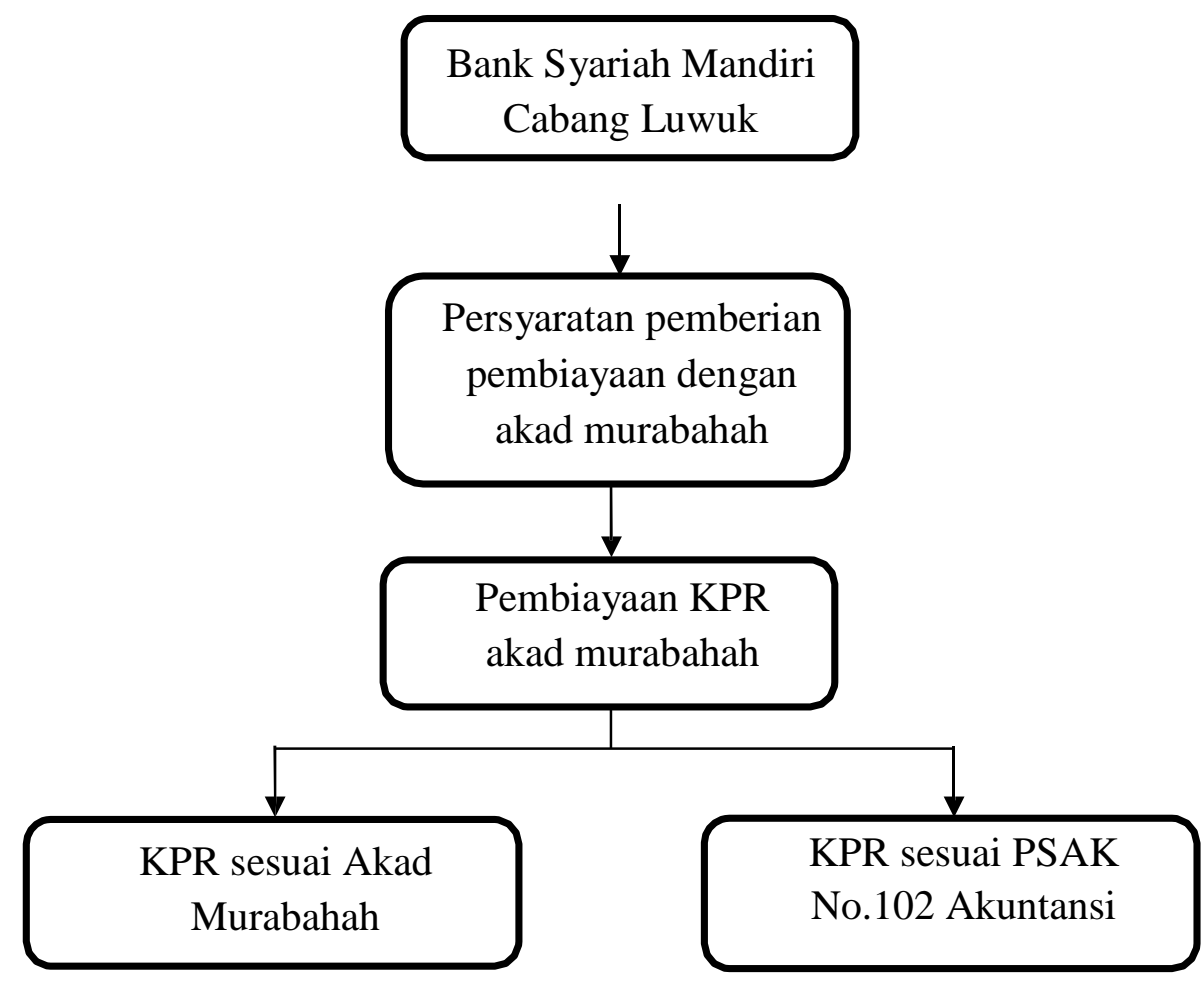

Gambar 1. Kerangka Pikir

\section{METODE}

Penelitian ini dilakukan pada Bank Syariah Mandiri Cabang Luwuk yang beralamat di Jl. Urip Sumoharjo No. 18 Luwuk, Kelurahan Keraton, Kabupaten Banggai, Provinsi Sulawesi Tengah.

Jenis dan Sumber data. Jenis data yang digunakan adalah data kualitatif: data yang berhubungan dengan karakteristik berwujud pertanyaan atau berupa kata-kata, seperti profil perusahaan dan prosedur pembiayaan KPR dengan menggunakan akad murabahah, dan data kuantitatif: data yang berwujud angka-angka. Seperti data-data perlakuan akuntansi dalam pembiayaan KPR dengan menggunakan akad murabahah pada tahun 2014.

Sedangkan sumber data yang digunakan data primer: data yang langsung diperoleh dari sumbernya, seperti prosedur pembiayaan KPR dengan menggunakan akad murabahah dan perlakuan akuntansi murabahah, dan data sekundar: data yang diperoleh denganmempelajari buku-buku, UU Bank Syariah, PSAK 102, artikel, dan jurnal yang berkaitan dengan objek penelitian. 
Metode Pengumpulan Data. Penulis menggunakan metode pengumpulan data, yaitu: 1) metode dokumentasi mengumpulkan data sekunder yaitu pencatatan akuntansi pembiayaan KPR dengan menggunakan akad murabahah; 2) metode wawancara: dengan mengadakan tanya jawab secara langsung dengan pihak-pihak yang terkait dengan pelaksanaan pembiayaan KPR dengan menggunakan akad murabahah; 3) metode kepustakaan: dengan membaca dan mempelajariteori-teori yang berhubungan erat dengan permasalahan pembiayaan KPR dengan menggunakan akad murabahah.

Definisi Operasional Variabel. Dalam penelitian ini memiliki dua variabel yaitu, variabel produk pembiayaan KPR dengan akad murabahah:

Pembiayaan Menurut IAI (2009: 31 paragraf 11), adalah peminjaman uang atau tagihan yang dapat dipersamakan dengan itu berdasarkan persetujuan atau kesepakatan pinjammeminjam antara bank dan pihak lain yang mewajibkan pihak peminjam untuk melunasi utangnya setelah jangka waktu tertentu dengan jumlah bunga, imbalan atau pembagian hasil keuntungan.

Menurut PSAK nomor 102, Murabahahadalah akad jual beli barang dengan harga jual sebesar biaya perolehan ditambah keuntungan yang disepakati dan penjual harus mengungkap. Persyaratan pemberian pembiayaan KPR dengan akad murabahah adalah pihak nasabah mengajukan rumah yang ingin dibeli kemudian pihak bank akan mengevaluasi apakah nasabah layak di danai (murabahah berdasarkan pesanan), dan bagi hasil atas pembiayaan sesuai dengan akad atau kesepakatan. Pembiayaan KPR dengan akad murabahah adalah pembiayaan jual beli dengan objek pembiayaan rumah yang sesuai dengan prinsip syariah.

Data yang dikumpulkan berupa persyaratan pembelian pembiayaan dengan akad murabahah kemudian dianalisis apakah telah memenuhi syarat pembiayaan dengan akad murabahah kemudian membandingkan antara pembiayaan KPR dengan akad murabahah yang diterapkan pada Bank Syariah Mandiri (BSM) Cabang Luwuk dengan prinsip-prinsip syariah yang terdapat dalam PSAK nomor 102 tentang Akuntansi Murabahah.

Metode Analisis Data. Penulis menggunakan metode analisis data deskriptif kualitatif, yaitu dengan menggambarkan keadaan objek penelitian yang sesungguhnya untuk mengetahui penerapan pembiayaan KPR dengan menggunakan akad murabahah pada Bank Syariah Mandiri (BSM) Cabang Luwuk.

\section{HASIL DAN PEMBAHASAN}

Penerapan Akuntansi Murabahah Terhadap KPR. Kredit kepemilikan rumah merupakan pembiayaan murabahahyang bersifat konsumtif. Dimana bank menyediakan pinjaman data untuk membeli rumah, tanah kavling atau untuk merenovasi rumah yang diperlukan calon penerima kredit, untuk dibayar kembali saat jatuh tempo dengan cara cicilan dan batas maksimal cicilan selama 15 tahun. Pada saat akad, pembiayaan KPR diakui pada saat pencairannya sebesar pokok pembiayaan yang diberikan dan keuntungan yang disepakati.

Dalam pembiayaan KPR pada Bank Syariah Mandiri Cabang Luwuk, keuntungan disebut margin yang merupakan pendapatan bank, dimana besarnya margin telah ditetapkan oleh Bank Syariah Mandiri Cabang Luwuk.Margin 1-5 tahun sebesar 8,5\%, 610 tahun sebesar $9,5 \%$ dan $11-15$ tahun $10,5 \%$. 
Pembiayaan KPR dengan akad murabahah wajib menggunakan uang muka. Apabila permohonan KPR yang diajukan nasabah adalah rumah bekas (second), nasabah wajib membayar uang muka sebesar 30\% dari harga jual rumah. Namun jika permohonan KPR yang diajukan adalah rumah baru, untuk rumah tipe $>70 \%$ nasabah wajib membayar uang muka sebesar $30 \%$ dan untuk rumah tipe $<70 \%$ nasabah wajib membayar uang muka sebesar $20 \%$.

Pemberian pembiayaan ini Bank Syariah Mandiri Cabang Luwuk mengenakan biaya yang langsung dibayar oleh nasabah ketika akad berlangsung. Adapun biaya-biaya antara lain: 1) Biaya administrasi sebesar $1 \%$ dari pembiayaan; 2) Biaya asuransi jiwa dan asuransi kebakaran yang besarnya tergantung usia nasabah; 3) Bea Balik Nama (BBN), dan 4) Biaya pengikatan. Bank Syariah Mandiri Cabang Luwuk akan meminta jaminan berupa Surat Hak Milik (SHM) dari rumah yang dibeli.Untuk lebih jelasnya bagaimana bagaimana pengakuan dan pengukuran transaksi KPR pada Bank Syariah Mandiri Cabang Luwuk, dapat dilihat dari contoh perhitungan berikut Pada tanggal 3 Maret 2013, Nurdin mengajukan permohonan pembiayaan untuk pembelian sebuah rumah dengan harga Rp.300.000.000,- dimana Nurdin membayar uang muka sebesar 20\% (Rp. 60.000.000,-) kepada developer, setelah bank melakukan penilaian terhadap permohonan tersebut Nurdin memiliki kesanggupan mengangsur selama 4 tahun (48 bulan). Bank melakukan kesepakatan dengan mengambil margin keuntungan 8,5\% / tahun. Maka penyelesaiannya sebagai berikut :

$$
\begin{array}{ll}
\text { Harga rumah } & =\text { Rp. } 300.000 .000,- \\
\text { Uang muka } & =(\text { Rp. } 60.000 .000,-) \\
\text { Nilai KPR } & =\text { Rp. } 240.000 .000,- \\
\text { Margin = } & 8,5 \% \text { x } 4 \text { x Rp. } 240.000 .000=\text { Rp. 81.600.000,- } \\
\text { Jadi, diperoleh margin sebesar Rp. } 81.600 .000,- \text { selama } 4 \text { tahun. } & =\frac{\text { Rp. } 81.600 .000}{48}=\text { Rp. } 1.700 .000,-
\end{array}
$$

Angsuran per tahun $=\underline{(\text { Pokok } x \text { margin } \mathrm{x} \text { jangka waktu })+\text { pokok }}$

$$
\begin{aligned}
& =\frac{\text { Jangka waktu }}{\text { Rp.240.000.000 x 8,5\% x 4)+Rp.240.000.000 }} \\
& =\text { Rp. 80.400.000,- }
\end{aligned}
$$

Jadi, diperoleh angsuran per tahun sebesar Rp.80.400.000,-.

Angsuran per bulan $=\underline{\text { Rp. 80.400.000,- }}$

$$
12
$$

$$
=\text { Rp. 6.700.000,- }
$$

Jadi, diperoleh angsuran per bulan sebesar Rp.6.700.000,-.Maka Bank Syariah Mandiri Cabang Luwuk menjurnal sebagai berikut :

- Saat realisasi pembiayaan

Aktiva murabahah Rp240.000.000,-

Utang pembelian murabahah

- Saat penjualan rumah

Piutang murabahah

Aktiva murabahah

- Saat menerima pendapatan administrasi Kas

Pendapatan administrasi
Rp 2.400.000,-

$$
\text { Rp240.000.000,- }
$$

Rp240.000.000,-

Rp240.000.000,-

Rp 2.400.000,- 
- Saat pembayaran bank kepada developer

Utang pembelian rumah

Rp240.000.000,-

Kas

Rp240.000.000,-

- Saat menerima angsuran dari Nurdin

Tabungan Nurdin

Piutang murabahah

Rp 6.700.000,-

Rp 6.700.000,-

- Saat pengakuan pendapatan

Pendapatan diterima dimuka

Pendapatan margin

Rp1.700.000,- $\operatorname{Rp1.700.000,-}$

Pada saat penandatanganan pernyataan serah terima (akad KPR) dengan akad murabahah di Bank Syariah Mandiri Cabang Luwuk terdapat poin-poin sebagai berikut: 1) Definisi akad murabahah; 2) Harga barang; 3) Bentuk pembiayaan; 4) Denda dan ganti rugi, 5) Jangka waktu pembiayaan; 6) Realisasi murabahah; 7) Pelunasan pembelian; 8) Jaminan pembiayaan, 9) Asuransi barang jaminan; 10) Asuransi jiwa; 11) Biaya dan pajak, 12) Penyelenggaraan rekening; 13) Kuasa bank atas rekening penerima pembiayaan; 14) Hak bank untuk mengakhiri jangka waktu pembiayaan; 15) Hal-hal yang harus dilakukan penerima pembiayaan; 16) Pembatasan terhadap tindakan penerima pembiayaan; 17) Peristiwa cidera janji (wanprestasi); 18) Keadaan memaksa (force majeur); 19) Penyelesaian sengketa.

Analisis Penerimaan Permohonan Pembiayaan Kredit Kepemilikan Rumah (KPR). Permohonan pembiayaan dan syarat-syarat KPR diajukan ke Bank Syariah Mandiri Cabang Luwuk lalu tim pembiayaan KPR memverifikasi kelengkapan berkas syarat-syarat KPR setelah berkas dinilai telah lengkap maka pihak bank meninjau ke lapangan (On The Spot) atau melihat langsung rumah yang akan dibeli, memverifikasi calon nasabah apakah berkas yang diberikan sesuai dengan keadaan yang sebenarnya dari calon nasabah.

Analisis yang digunakan oleh Bank Syariah Mandiri Cabang Luwuk adalah analisis lima C yaitu:

1. Character. Character adalah keadaan watak/sifat dari calon penerima pembiayaa, baik dalam kehidupan pribadi maupun dalam lingkungan usaha.Untuk mengetahui karakter calon penerima pembiayaan maka dilakukan wawancara dari jawaban pertanyan- pertanyaan yang diajukan dapat diketahui karakter calon penerima pembiayaan. Bank Syariah Mandiri Cabang Luwuk juga mencari informasi Bank Indonesia tentang calon penerima pembiayaan apakah calon penerima pembiayaan mempunyai hutang di bank lain dan apakah calon penerima pembiayaan mempunyai kredit macet.

2. Capital. Capital merupakan modal atau penghasilan yang dimiliki ataupun yang diterima oleh calon penerima pembiayaan. Untuk menghitung penghasilan minimal dari calon penerima pembiayaan agar dapat diterima pembiayaannya maka cicilan kredit kepemilikan rumah (KPR) haruslah minimal $40 \%$ dari penghasilannya. Misalkan cicilan kredit kepemilikan rumah (KPR) sebesar Rp.2.000.000,- maka penghasilan minimalnya adalah Rp.2.000.000,-/40\% = Rp.5.000.000,-. Jika penghasilan calon penerima dibawah Rp.5.000.000,- maka permohonan pembiayaan akan ditolak.

3. Capacity. Capacity merupakan kapasitas calon penerima pembiayaan (pengusaha) dalam mengelola modal untuk mendapatkan laba dalam memenuhi kewajibannya.Bagi 
calon penerima pembiayaan yang bekerja pada perusahaan maka perusahaan dan jabatan tempat bekerja juga menentukan dalam penerimaan permohonan pembiayaan.

4. Collateral. Setiap pemberian pembiayaan harus disertai dengan jaminan fisik yang jumlah dan nilainya harus dapat menjamin besarnya pembiayaan yang disetujui.Jaminan pembiayaan harus benar-benar dapat dikuasai serta diyakini kebenaran status pemiliknya.Sehingga, bila di kemudian hari nasabah tidak mampu membayar kewajibannya, maka jaminan ini dapat dijadikan sebagai alat pengamanan atas pembiayaan yang diberikan.

5. Condition of Economy. Condition of Economy merupakan situasi kondisi politik, sosial, ekonomi dan budaya yang mempengaruhi keadaan perekonomian yang kemungkinan pada suatu saat mempengaruhi kelancaran perusahaan atau tempat calon penerimaan pembiayaan bekerja., yang sangat diperhatikan dalam analisis $5 \mathrm{C}$ adalah karakter bila calon penerima pembiayaan dianggap memiliki karakter yang buruk walaupun memiliki penghasilan yang cukup maka permohonan pembiayaan akan di tolak. Jika jaminan yang besar tidak diikuti dengan kemampuan untuk membayar angsuran maka permohonan pembiayaan juga akan ditolak.

Setelah memperoleh keyakinan atas keabsahan dokumen dari hasil penyelidikan dan wawancara maka langkah selanjutnya adalah memberikan keputusan, menerima atau menolak pembiayaan tersebut. Bila telah dianggap layak menerima pembiayaan, maka persetujuan pembiayaan diberikan oleh Marketing Officer, yang dituangkan dalam Nota Analisa Pembiayaan (NAP).

Selanjutnya Nota Analisa Pembiayaan (NAP) akan diajukan oleh Marketing Officer kepada Pimpinan Cabang untuk meminta persetujuan pembiayaan. Jika Pimpinan Cabang menyetujui pembiayaan tersebut maka akan dinyatakan dalam Surat Keputusan Pembiayaan (SKP) yang telah dibuat oleh Administrasi Pembiayaan .

Dari hasil penelitian diperoleh bahwa pembiayaan murabahah yang dilakukan oleh Bank Syariah Mandiri Cabang Luwuk secara umum telah sesuai dengan PSAK No.102. Kesesuaian penerapan pembiayaan murabahah yang terkait dengan PSAK No.102 adalah:

1. Bank Syariah Mandiri Cabang Luwuk dalam melaksanakan pembiayaan murabahah bertindak sebagai penjual dengan menyatakan harga jual dan keuntungan yang telah disepakati antara pihak bank dan nasabah. Namun dalam menentukan margin, Bank Syariah Mandiri Cabang Luwuk telah menetapkan besarnya margin. Tidak terjadi tawar menawar antara nasabah dengan Bank Syariah Mandiri Cabang Luwuk dalam menetapkan besarnya margin. Hal ini sesuai dengan Akuntansi Murabahah yang menyatakan bahwa dalam sistem pembiayaan transaksi murabahah bank bertindak sebagai penjual dan nasabah bertindak sebagai pembeli atas barang dan dinilai sebesar harga jual ditambah keuntungan. (PSAK No.102 : Akuntansi Murabahah, paragraf 06). Namun tidak sesuai dengan prinsip syariah.

2. Bank Syariah Mandiri Cabang Luwuk meminta nasabah untuk membayar uang muka sebesar 20\% hingga 30\% yang akan menjadi bagian pelunasan pembiayaan. Hal ini sesuai dengan Akuntansi Murabahah yang menyatakan bahwa bank dapat meminta uang muka kepada nasabah yang merupakan bagian dari pelunasan pembiayaan. (PSAK No.102 : Akuntansi Murabahah, paragraf 14).

3. Bank Syariah Mandiri Cabang Luwuk mengakui keuntungan murabahah secara proposional dengan besaran kas yang berhasil ditagih dari piutang murabahah. Hal ini sesuai dengan Akuntansi Murabahah yang menyatakan bahwa keuntungan diakui pada 
saat penyerahan asset murabahah atau secara proporsional dengan besaran kas yang berhasil ditagih dari piutang murabahah. (PSAK No.102: Akuntansi Murabahah.

\section{PENUTUP}

Simpulan. Bank Syariah Mandiri Cabang Luwuk telah menerapkan pembiayaan yang operasionalnya sesuai dengan ketentuan yang berlaku yaitu Pernyataan Standar Akuntansi Keuangan (PSAK) Nomor 102 tentang Akuntansi Murabahah. Didalam pelaksanaan pembiayaan murabahah, Bank Syariah Mandiri Cabang Luwuk bertindak sebagai penjual dan nasabah sebagai pembeli; Analisis lima $\mathrm{C}$ sebagai dasar pertimbangan pemberian kredit kepemilikan rumah (KPR) di Bank Syariah Mandiri Cabang Luwuk; Perbedaan antara bunga bank konvesional dan bank syariah dilihat dari penetapan margin, untuk penetapan margin pembiayaan KPR pada bank syariah perhitungannya fix (tetap sesuai akad) apabila dalam tahun pembiayaan terjadi kenaikan suku bunga, nasabah akan membayar angsuran sesuai margin yang telah disepakati dalam akad. Beda halnya dengan bank konvensional, pembayaran angsuran harus disesuaikan dengan besarnya suku bunga jika terjadi kenaikan.

saran adalah Seharusnya dalam menetapkan margin Bank Syariah Mandiri Cabang Luwuk harus sesuai dengan prinsip syariah yaitu adanya tawar menawar dalam kesepakatan penentuan margin untuk pembiayaan KPR antara pihak bank dan nasabah; agar KPR di Bank Syariah Mandiri Cabang Luwuk lebih diminati masyarakat, bank seharusnya bisa melaksanakan prosedur serta realisasi pembiayaan murabahah dengan cepat untuk kenyamaan antara nasabah dan Bank Syariah Mandiri Cabang Luwuk.

\section{DAFTAR RUJUKAN}

Ismail, (2013) Perbankan Syariah, edisi ke dua Yogyakarta,

Adiwarman A. Karim, (2010) Analisis Fiqih dan Keuangan, Jakarta: PT Raja Grafindo Persada. Agustianto, Percikan Pemikiran Ekonomi.

Muhammad, (2005) Manajemen Bank Syariah, UPP AMP YKPN, Yogyakarta.

Sri Nurhayati, Wasilah. (2011) Akuntansi Syariah di Indonesia, edisi kedua revisi, Jakarta: Salemba Empat.

Sumitro, Warkum. (2004) Asas-asas Perbankan Syariah, dan Lembaga-lembaga Terkait. Jakarta: PT Raja Grafindo Persada.

Antonio, Muhammad Syafi'i. (2001) Bank Syariah, dari Teori ke Praktik. Jakarta: Gema Insani Pres.

Al-Qur'anul Karim dan Terjemahannya Tafsir.

IAI, (2009) Pernyataan Standar Akuntansi Keuangan. Jakarta: Salemba Empat.

Undang-undang Republik Indonesia Nomor 7 Tahun 1992 tentang Perbankan.

Undang-undang Republik Indonesia Nomor 10 Tahun 1998 tentang Perubahan Atas Undang-undang Nomor 7 Tahun 1992 tentang Perbankan.

Undang-undang Republik Indonesia Nomor 21 Tahun 2008 tentang Perbankan Syariah. 2008. Jakarta: Departemen Keuangan Republik Indonesia.

Surat Edaran Mahkamah Agung nomor 8 Tahun 2010. Tentang Eksekusi Putusan Badan Arbitrase Syariah.

Peraturan Bank Indonesia Nomor 11/3/PBI/2009/ tentang Bank Umum Syariah. 
www. Pembiayaan murabahah pada bank syariah.com,(24 April 2014).

www.pcinu-mesir.tripod.com/ilmiah/artikel/isartikel/artikel/Artikel96-02/yopi_ syaltut.htm, (12 Mei 2014). 